\title{
Effect of Integrated Technology on Self Concept of 13 To 16 Years Old Students
}

\author{
Shukla R. ${ }^{1 *}$, Dr. Upadhyaya H. ${ }^{2}$
}

\section{ABSTRACT}

The main objective of the present research work was to see the effect of integrated technology on the self concept of 13 to 16 years old students, for achieving this objective a purposeful sample of 13 to 16 years old 140 students from urban and rural areas of Jabalpur district were taken and was divided into experimental\& control group. The researcher first administered scale of self concept (by Dr. R.K. Saraswat) as pre-test, followed by 30 days treatment, after treatment again post-test was administered (S.C.S.) on both the groups. Gain scores were obtained (Post testPretest $=$ Gain score). For analysis of data $2 \times 2 \times 2$ Analysis of variance (ANOVA) was used. Results revealed that a significant main difference was found for area, gender and method at 0.01 level of significance.

Keywords: Integrated Technology, Self-concept, Tradition method of teaching.

One of the main goals of education is to help children discover the self in the perspective of coherent view of the world. Rogers (1951) suggests self as the nuclear concept of personality. It is conceived as it develops with his environment. Bookover and Thomas (1964) in their study found that there is a significant positive correlation between self concept and performance in academic role.

Morris D. Caplin (1969) in an experimental study found that there is a significant positive relationship between self concept and academic achievement. Mishr \& Shukla (2008) found that when self concept, increases, creativity also increases. Deshmukh \& Sawalakhe (2010) found significant positive correlation among self concept, Emotional intelligence and adjustments of adults. Kumar (2012) found positive relationship between ego strength and self concept, Jha \& Paul (2012) revealed in their study that there is a significant difference between the self concept of disciplined and non disciplined group of students. Reviews also tell that self concept starts

\footnotetext{
${ }^{1}$ Research Scholar, Rani Durgavati Vishwavidhyalaya, Jabalpur, M.P., India

${ }^{2}$ H.O.D Education Department, Hawabagh Women’s College, Jabalpur, M.P., India

*Responding Author

(C) 2016, R Sukla, H Upadhyay; licensee IJIP. This is an Open Access Research distributed under the terms of the Creative Commons Attribution License (http://creativecommons.org/licenses/by/2.0), which permits unrestricted use, distribution, and reproduction in any Medium, provided the original work is properly cited.
} 


\section{Effect of Integrated Technology on Self Concept of 13 To 16 Years Old Students}

when babies can recognize themselves in a mirror (Chales Darwin), self awareness begins around 6 months of age (courage, \& Howe, 2002; Damon \& Hart, 1982; 1988; 1992) Children of 8 to 10 years of age can make comparisons of themselves to others. Maccoby (1980) told that how children see themselves also influences how they act. According to above researchers, self concept has a positive effect upon achievement, creativity, emotional intelligence, adjustment and disciplinedness, reviews also tell that self concept begins in babies very early when they can recognize themselves in mirror and gradually increases by their age. It is conceived and developed as a result of the interaction of individual with environment. Reviews developed a curiosity in the investigator that Do teaching methods have an effect on self concept? To find out the answer researcher reviewed teaching methods and found that Integrated technology based class rooms are very popular and changing the classroom environment rapidly. Bhadauria (2010) in his experimental study found a positive effect of computer aided teaching on achievement. Amrutha (2010) found in her study that e-content had a significant effect in teaching Kay \& Robin (2011) studied that if selected carefully WBLT'S (Web Based Learning Tools) can be a positive learning tool in the middle school environment, Vaidya \& Upadhyaya (2015) concluded in their research that the educompsmart class programme has a positive impact on students and is found to be significantly superior to lecture method in improving the intelligence. As suggested by the reviews technology based or assisted class rooms have a positive effect on academic achievement of students and are good learning tools but the question which is arising in researchers mind is does the integrated technology has similar effect on self concept ? Driven by this question present research work is planned.

\section{Statement of the Problem}

"Effect of Integrated Technology on self concept of 13-16 years old students".

\section{Objective of the study}

For experimental verification following objective is framed.

1. To study gender and area wise effect of integrated technology and their interaction on self concept of 13 to 16 years old students.

\section{Hypothesis}

1. There is no significant gender and area wise effect of integrated technology and their interaction on self-concept of 15 to 16 years old students.

\section{METHODOLOGY}

Non equivalent control group design is used. Sample - A sample of 140 students of 13 to $16 \mathrm{yrs}$. Were select from urban and rural areas of Jabalpur District (M.P.) [Rural-75 (47 girls \& 28 boys)] [ Urban -65 (21 girls \& 44 boys)]. 


\section{Tools of study}

For independent variable, Integrated Technology assisted lesson plans were used, and for measuring dependent variable scale of self concept by Dr. R.K. Saraswat was used.

\section{Procedure}

For collection of the data for present work scale of self concept was administered as a pre-test on experimental \& control groups, followed by a 30 days treatment on both the groups after that a post test was administered (same scale of self concept) on both the groups. Gain scores were obtained after scoring (Post test score-Pre test score $=$ Gain score)

\section{Statistical Analysis -}

Data was analyzed by Two Way Analysis of Variance (ANOVA)

\section{RESULT \&INTERPRETATION}

\section{Table No.1, Summary Table of ANOVA for Dependent Variable (Self Concept gain)}

\begin{tabular}{|l|l|l|l|l|}
\hline Source & df. & $\begin{array}{l}\text { Sum Squares } \\
(\mathrm{SS})\end{array}$ & $\begin{array}{l}\text { Mean squares } \\
(\mathbf{M S})\end{array}$ & $\mathbf{F}$ \\
\hline Method & 1 & 320.818 & 320.818 & $6.302^{* *}$ \\
\hline Gender & 1 & 544.684 & 544.684 & $10.700^{* *}$ \\
\hline Area & 1 & 494.597 & 494.597 & $9.716^{* *}$ \\
\hline Method *Gender & 1 & 77.386 & 77.386 & 1.520 \\
\hline Method* Area & 1 & 4.560 & 4.560 & .090 \\
\hline Gender * Area & 1 & 3.239 & 3.239 & .064 \\
\hline Method \& Gen. * Area & 1 & 64.410 & 64.410 & 1.265 \\
\hline Error & 132 & 6719.593 & 50.906 & \\
\hline Total & 140 & 37033.000 & & \\
\hline$* *$ Signifant & &
\end{tabular}

** Significant at 0.01 level of significance

Table No.2, Method, Gender, Area wise, Mean, Standard Deviation, \& Number of 13-16 years old students for self concept

\begin{tabular}{|c|c|c|c|c|c|}
\hline Method & Gender & Area & Mean & $\begin{array}{l}\text { Std. } \\
\text { Deviation }\end{array}$ & N. \\
\hline \multirow{9}{*}{$\begin{array}{l}\text { Integrated } \\
\text { Technology }\end{array}$} & \multirow{3}{*}{ Girls } & Rural & 15.9310 & 7.79162 & 29 \\
\hline & & Urban & 10.3077 & 4.46065 & 13 \\
\hline & & Total & 14.1905 & 7.36252 & 42 \\
\hline & \multirow{3}{*}{ Boys } & Rural & 20.6923 & 7.81435 & 13 \\
\hline & & Urban & 17.3571 & 11.90738 & 14 \\
\hline & & Total & 18.9630 & 10.09753 & 27 \\
\hline & \multirow{3}{*}{ Total } & Rural & 17.4048 & 8.01845 & 42 \\
\hline & & Urban & 13.9630 & 9.64158 & 27 \\
\hline & & Total & 16.0580 & 8.78482 & 69 \\
\hline
\end{tabular}

(c) The International Journal of Indian Psychology, ISSN 2348-5396 (e)| ISSN: 2349-3429 (p) | 180 
Effect of Integrated Technology on Self Concept of 13 To 16 Years Old Students

\begin{tabular}{|c|c|c|c|c|c|}
\hline Method & Gender & Area & Mean & \begin{tabular}{|l|} 
Std. \\
Deviation
\end{tabular} & N. \\
\hline \multirow{9}{*}{$\begin{array}{l}\text { Traditional } \\
\text { Method }\end{array}$} & \multirow{3}{*}{ Girls } & Rural & \begin{tabular}{|l|}
12.3889 \\
\end{tabular} & 4.00204 & 18 \\
\hline & & Urban & 10.5000 & 4.50397 & 8 \\
\hline & & Total & 11.8077 & 4.16672 & 26 \\
\hline & \multirow{3}{*}{ Boys } & Rural & 16.8667 & 9.00688 & 15 \\
\hline & & Urban & 11.3667 & 4.75237 & 30 \\
\hline & & Total & 13.2000 & 6.89730 & 45 \\
\hline & \multirow{3}{*}{ Total } & Rural & 14.4242 & 7.00906 & 33 \\
\hline & & Urban & 11.1842 & 4.65487 & 38 \\
\hline & & Total & \begin{tabular}{|l|}
12.6901 \\
\end{tabular} & 6.04647 & 71 \\
\hline \multirow{9}{*}{ Total } & \multirow{3}{*}{ Girls } & Rural & 14.5745 & 6.77510 & 47 \\
\hline & & Urban & 10.3810 & 4.36436 & 21 \\
\hline & & Total & 13.2794 & 6.40393 & 68 \\
\hline & \multirow{3}{*}{ Boys } & Rural & 18.6429 & 8.54277 & 28 \\
\hline & & Urban & \begin{tabular}{|l|}
13.2727 \\
\end{tabular} & 8.12794 & 44 \\
\hline & & Total & 15.3611 & 8.64366 & 72 \\
\hline & \multirow{3}{*}{ Total } & Rural & 16.0933 & 7.68673 & 75 \\
\hline & & Urban & 12.3385 & 7.22469 & 65 \\
\hline & & Total & 14.3500 & 7.68248 & 140 \\
\hline
\end{tabular}

\section{Effect of Method on Self Concept}

From Table no.1 indicates that there was significant main effect for methods at .01 level of significance [ $\mathrm{F}=(\mathrm{df}-1 / 132)=6.302]$. It means that there is a significant difference between the gain scores of self concept of 13 to 16 years old students who were taught by integrated technology and those who were taught by traditional method of teaching. Therefore the null hypothesis "There is no significant effect of integrated technology on self concept of 13 to 16 years old students." is rejected, further it is clear from table no. 2 that the mean score of self concept of 13 to 16 yrs. Old students who were taught by integrated technology was 16.0580 , which was significantly higher than that of 13 to 16 years old students who were taught by traditional method (12.6901) as shown in Graph no.1 .

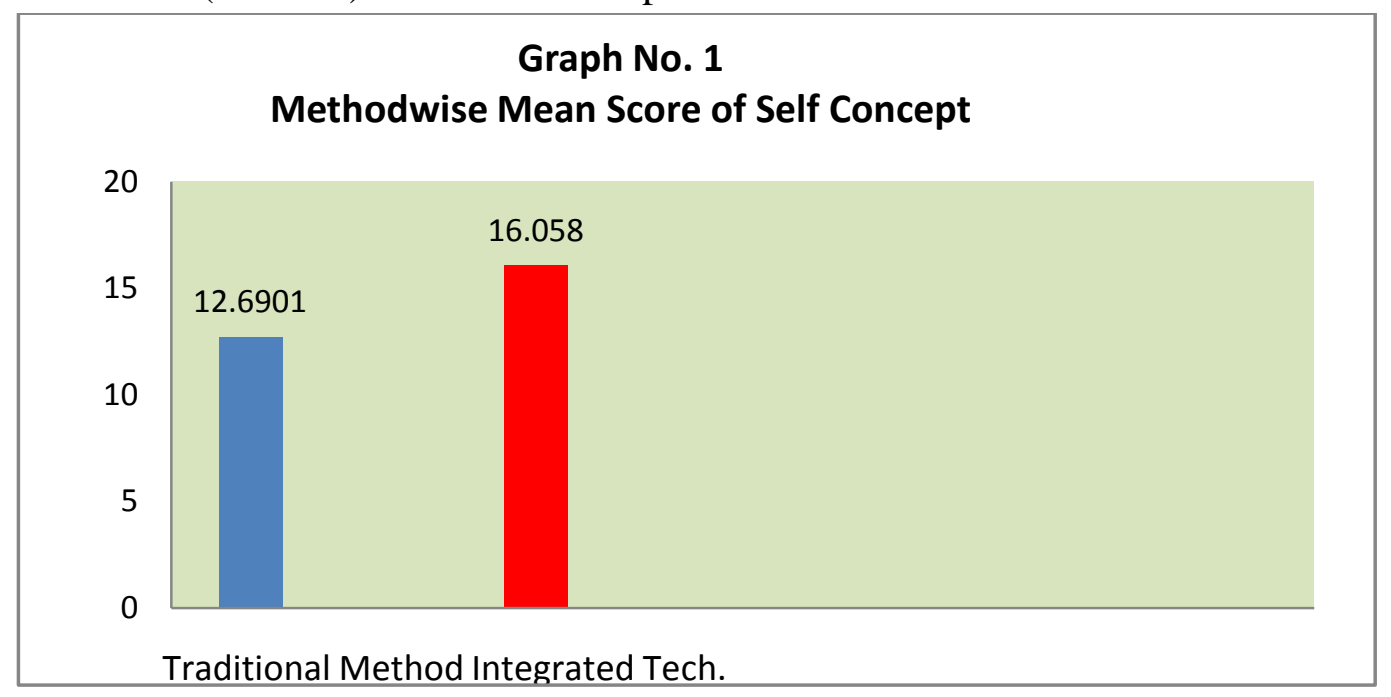

(c) The International Journal of Indian Psychology, ISSN 2348-5396 (e)| ISSN: 2349-3429 (p) | 181 


\section{Effect of Integrated Technology on Self Concept of 13 To 16 Years Old Students}

\section{Effect of Gender on Self Concept}

There was a significant main effect of gender $[\mathrm{F}=(\mathrm{df}-1 / 132)-10.700]$ at 0.01 level of significance. It means that there was a significant difference between 13 to 16 years old boys a girls for self concept Therefore null hypothesis "There is no significant gender wise effect of integrated technology on self concept of 13 to 16years old students "is rejected, further it is clear from the table no.2 that the mean score of self concept of 13 to 16 years old boys was 15.3611 which is significantly higher than that of girls of 13 to 16 years old (13.2794) as shown in Graph no.2.

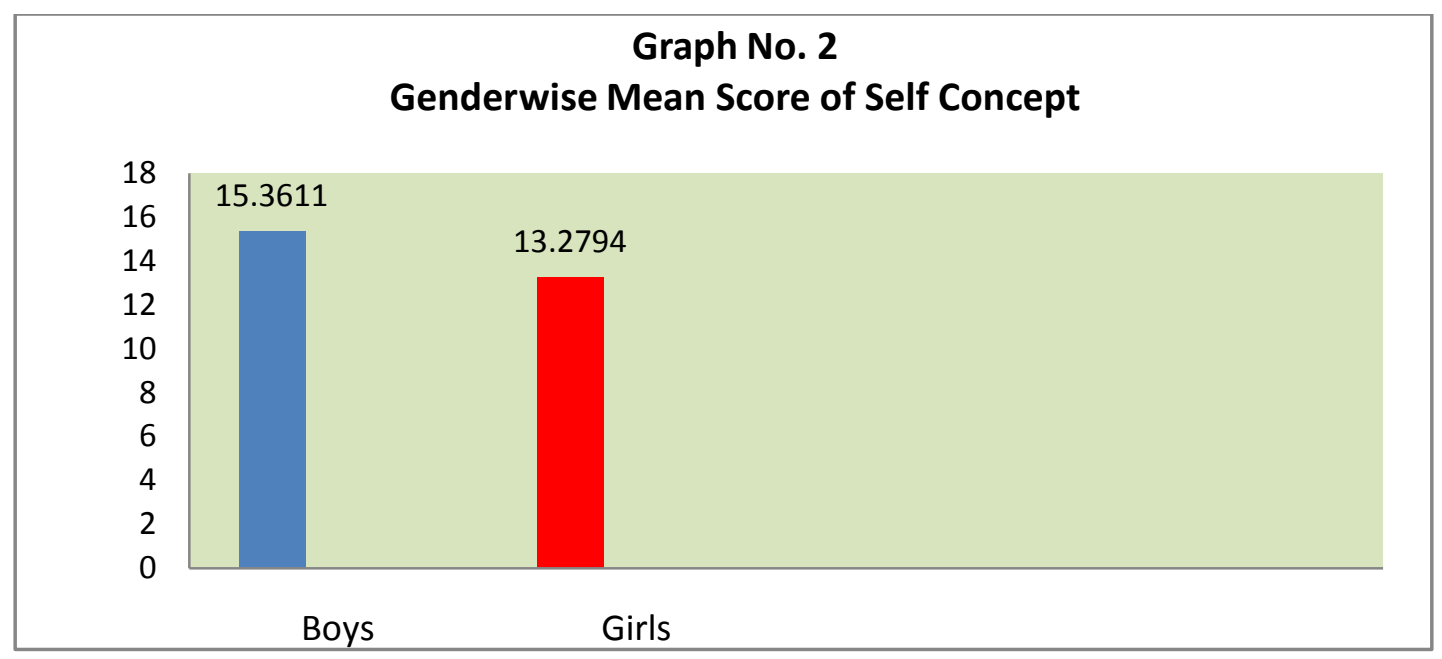

\section{Effect of Area on Self Concept}

From Table no. 1 shows that there was a significant main effect for area [F=df-1/132)] -9.716 at 0.01 level of significance. It means that there was a significant difference between 13 to 16 years old students who belong to urban and rural area of Jabalpur district. Therefore null hypothesis, "There is no significant area wise effect of integrated technology on self-concept of 13 to 16years old students." is rejected, further it is clear from the table no.2 that the means score of self concept of 13 to 16 years old student who belong to rural area was 16.0933 which is significantly higher than that off 13 to 16 years old students of urban area (12.3385)as shown in Graph no. 3.

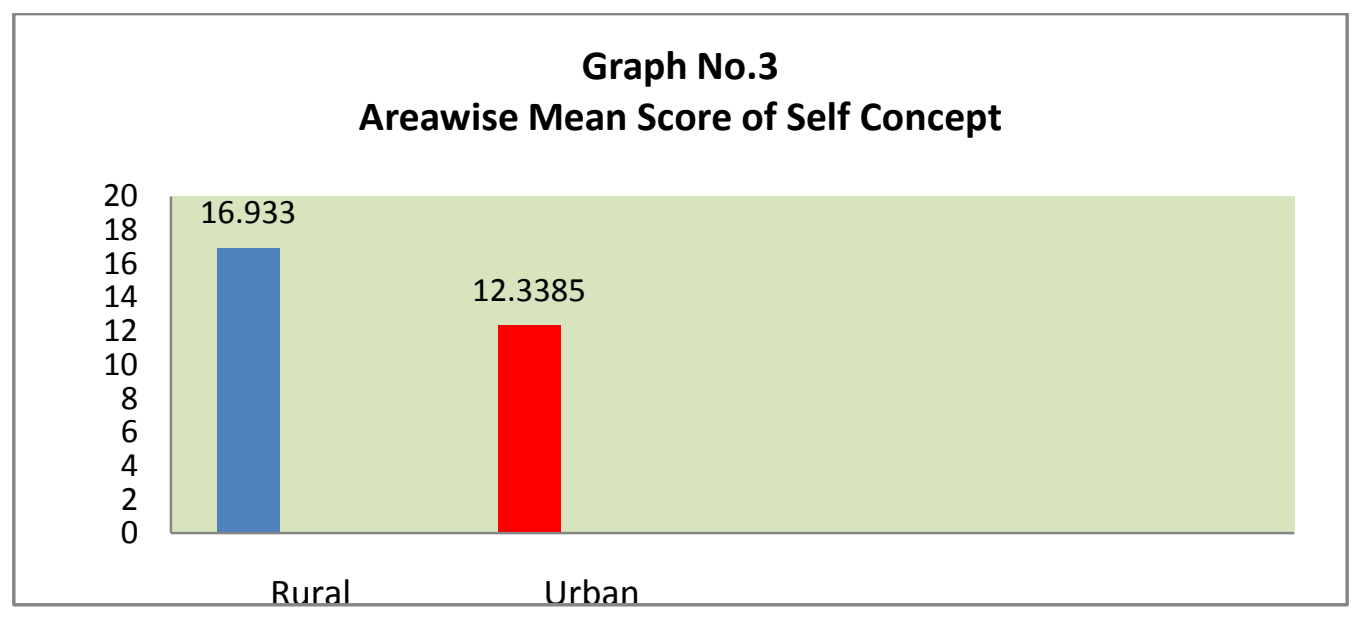

(c) The International Journal of Indian Psychology, ISSN 2348-5396 (e)| ISSN: 2349-3429 (p) | 182 


\section{Effect of Method and Gender on Self Concept}

From Table no. 1 clearly stated that there was no significant interactional effect for method and gender $[\mathrm{F}=\mathrm{df}-1 / 132=1.520]$ at 0.05 level. It means that there was no significant difference between scores of self concept of 13 to 16 years old boys and girls who were taught by integrated technology. Therefore null hypothesis" There is no significant gender wise interactional effect on self concept of 13 to 16 years old students" is not rejected.

\section{Effect of Method and Gender on Self Concept}

From Table no. 1 clearly stated that there was no significant interactional effect for method and area $[\mathrm{F}=(\mathrm{df}-1 / 132)=.090]$ at 0.05 level of significance. It means there was no significant difference between scores of self concept of 13 to 16 years old students of urban and rural area when taught by integrated technology. Therefore null hypothesis" There is no significant area wise interactional effect on self-concept of 13 to 16 years old students" is not rejected.

\section{Effect of Gender and Area on Self Concept}

There was no significant interactional effect for gender and area $(F=(d f-1 / 132)=.064$ at 0.05 level of significance (vide table no.1). It means there was no significant difference between scores of self concept of 13 to 16 years old boys and girls who belong to urban and rural areas of Jabalpur district. Therefore null hypothesis "There is no significant gender and area wise interactional effect on self concept of 13 to 16 years old students" is not rejected.

\section{Effect of Method Gender and Area on Self Concept}

There was no significant interactional effect for method, gender and area [F=df-1/132 $=1.265]$ at 0.05 level of significance (Table no.1). It means there was no significant difference among scores of self concept of 13 to 16 years old boys and girls who belong to urban and rural areas of Jabalpur, when taught through integrated technology and traditional method.

\section{INTERPRETATION AND DISCUSSION}

On the basis of above result it is clear that there were significant difference found for method, gender and area for self concept of 13 to 16 years old students of Jabalpur district. No researches have been found to see the effect of integrated technology on self concept of 13 to 16 years old students, but during the research procedure the investigator realized that while teaching through integrated technology students get more exposure for development of self concept. While learning through the video clips they were more attentive, more conscious and happy.

It was noticeably found that self concept of 13 to 16 years old boys was significantly better than that of 13 to 16 years old girls. It may be because in Indian context girls are not given much exposure in comparison to boys, that is why self concept score of girls were comparatively lower than that of boys. It was also found that 13 to 16 years old students of rural area showed better self concept than 13 to 16 years old students of urban area. This may be because rural area 


\section{Effect of Integrated Technology on Self Concept of 13 To 16 Years Old Students}

students were exposed to integrated technology for the very first time whereas students of urban area keep interacting with the technological gadgets in the form of smart phones, television, movie theaters etc.

\section{CONCLUSION}

On the basis of above result \& interpretation a significant effect of integrated technology on self concept of 13 to 16 years old students of Jabalpur district was found.

\section{Acknowledgments}

The author appreciates all those who participated in the study and helped to facilitate the research process.

\section{REFERENCES}

Amrutha, S. (2010).Effect of E-content on the Achievement of Biology among Secondary Student.

Deshmukh, N. \& Sawalakhe, H. (2010).Self concept Emotional Intelligence and Adjustments of Adults, Indian Journal of Psychometery and Education, 41(2), 181-185.

Jha, R. \& Paul, S. (2012). A Comparative Study of Self Concept among Disciplined and Indisciplined Students at Higher Secondary Level. Research Link -94, Vol-X (11), January, 84-86.

Kumar, S. (2012) Self concept of seeing and Visually impaired School Students in Relation to their Ego Strength Research Link 94, Vol-X (11), 79-81.

Kay, \& Robin (2011) Exploring the Impact of Web-Based Learning Tools I Middle School Mathematics and Science Teaching. Journal of Computers in Mathematics and Science Teaching.V30n2, 141-162.

Mishra, S. \& Shukla, S. (2008) Effect of self concept upon creativity. CTE National Journal, Vol. 6, no.1.49-52.

Morris D. Caplin. "The Relationship Between Self Concept and Academic Achievement” The Journal of Experimental Education; Volume 37, No.3, spring 1969.

Vaidya, M. \& Upadhyaya, H. (2015) Effectiveness of Educomp. Smart class Program in Terms of Intelligence of Middle level School Students of Jabalpur. Research Link-139, Vol.XIV(8) Oct. 2015, 103-105.

W. B. Bookover and S. Thomas. "Self Concept of ability and School Achievement” Sociology of Education; spring 1964, Vol. 37. No. 3; Pp.271-278

(n.d.) Retrieved from https://www.boundless.com/psychology/human-development/ social development-in childhood/the-development-of self-concept.

How to cite this article: R Sukla, H Upadhyay (2016), Effect of Integrated Technology on Self Concept of 13 To 16 Years Old Students, International Journal of Indian Psychology, Volume 3, Issue 4, No. 63, ISSN 2348-5396 (e), ISSN: 2349-3429 (p), DIP: 18.01.112/20160304, ISBN: 978-1-365-32518-2 